\title{
PERANCANGAN APLIKASI E-COMMERCE PRODUK OBAT- OBATAN PADA APOTIK BAGJA CIREBON BERBASIS WEB
}

\author{
Dika Prasetyo Adhi', Wiwiek Nurkomala Dewi ${ }^{2}$ \\ Universitas Catur Insan Cendekia \\ J1. Kesambi 202, Kota Cirebon, Jawa Barat Tlp : (0231) 220250 \\ e-mail : dikadjunior18@gmail.com ${ }^{1}$,wiwiek.nurkomala.dewi@cic.ac.id²
}

\begin{abstract}
ABSTRAK
E-commerce merupakan perdagangan secara elektronik menjual barang atau jasa dengan memanfaatkan sebuah jaringan internet. Untuk meningkatkan kualitas pelayanan sebuah Apotik, Apotik Bagja yang bergerak dibidang perdagangan penjualan obat-obatan dan alat kesehatan ingin lebih memaksimalkan dalam memberikan sebuah kemudahan dan kenyamanan kepada konsumennya untuk berbelanja di Apotik Bagja. Membuat aplikasi e-commerce ini menjadi pendukung untuk mencapai keberhasilan meningkatkan pelayanan dan keuntungan penjualan di Apotik Bagja. Proses program ini dimulai dengan menganalisa sistem ada pada Apotik Bagja, Kemudian menyusun UseCase, dan tabel-tabel yang diperlukan. Membuat rancangan program. Aplikasi e-commerce berbasis web ini menggunakan bahasa pemograman PHP, MySQL sebagai sarana untuk membuat dan mengolah database dan Microsoft Visio. Proyek manajemen informatika menghasilkan aplikasi e-commerce berbasis web ini memiliki fungsu, yang pertama dibagian customer setiap pengunjung bisa melihat berbagai macam produk obat-obatan dan alat kesehatan Apotik Bagja dan memesannya sebelum itu wajib registrasi terlebih dahulu dan memasukan username dan password. Bagian yang kedua admin bisa melakukan pengelolaan data produk dan pesanan dan laporan.
\end{abstract}

Kata kunci : Aplikasi, Penjualan, Pemesanan, Laporan, Transaksi

\begin{abstract}
E-commerce is trading electronically to sell goods or services by utilizing an internet network. To improve the service quality of a pharmacy, Bagja Pharmacy, which is engaged in trading in the sale of medicines and medical devices, wants to maximize its ability to provide convenience and comfort for its consumers to shop at the Bagja Pharmacy. Making this e-commerce application a supporter to achieve success in improving service and sales profits at Bagja Pharmacies. The process of this program begins by analyzing the existing system at the Bagja Pharmacy, then compiling the Use Case, and the necessary tables. Create a program design. This web-based e-commerce application uses the PHP programming language, MySQL as a means to create and process databases and Microsoft Visio. The informatics management project that produces this web-based e-commerce application has a function, first in the customer section, each visitor can see various kinds of medicinal products and medical devices at the Bagja Pharmacy and order them before it is mandatory to register first and enter a username and password. The second part of the admin can manage product data and orders and reports
\end{abstract}

Keywords : application, sale, booking, report, transaction

\section{PENDAHULUAN}

Apotek Bagja merupakan sebuah apotik yang sedang berkembang dalam membantu masyarakat dengan memberikan solusi dari berbagai macam penyakit. Namun, apotik ini dalam penjualan masih bersifat konvesional dimana pemasukan dan pengeluaran masih menggunakan manual. Sehingga, kemungkinan akan menimbulkan peluang kesalahan dalam pencatatam dan resiko terjadinya human eror yang dapat terjadi kapanpun. Hal tersebut dapat diatasi dengan dirancangnya sebuah system informasi dan aplikasi database yang dapat menampung data dalam jumlah banyak. Sehingga dalam pengaksesan terhadap suatu data melalui proses aplikasi yang dibangun dapat memudahkan pengguna untuk memperoleh 
infomasi yang lebih cepat dan akurat serta mencegah terjadinya kesalahan pada proses pelayanan. Dengan permasalahan di atas, maka penulis tertarik untuk mengangkat judul "PERANCANGAN APLIKASI ECOMMERCE PRODUK OBAT-OBATAN PADA APOTIK BAGJA CIREBON BERBASIS WEB”. Dengan menggunakan metode deskriptif dengan studi kasus.

\section{KAJIAN PUSTAKA}

2.1 Aplikasi

Aplikasi menurut Dhanta dikutip dari Sanjaya (2015) adalah software yang dibuat oleh suatu perusahaan komputer untuk mengerjakan tugas-tugas tertentu, misalnya Microsoft Word, Microsoft Excel. Aplikasi berasal dari kata application yang artinya penerapan lamaran penggunaan

\subsection{Electronic Commerce (E-commerce)}

Menurut Nugroho (2016) E-commerce merupakan sebuah layanan internet yang dimanfaatkan untuk jual-beli secara online. Dengan e-commerce telah banyak merubah dalam proses jual-beli. Jika dalam suatu jual-beli penjual dan pembeli bertemu, mereka berinteraksi dengan melalui internet maupun dengan komunikasi melalui telepon atau chatting

\subsection{Web Server}

Menurut (Baiq Nonik.dkk,2017) Web Server adalah tempat anda mendapatkan halaman web dan data yang berhubungan dengan website yang anda buat, sehingga data dapat diakses dan dilihat oleh orang lain

\subsection{Website}

Menurut Rohi Abdulloh dari bukunya yang berjudul "Easy \& Simple Web Programming" (2016), Website atau disingkat web, dapat diartikan sekumpulan halaman yang terdiri atas beberapa informasi dalam bentuk data digital, baik berupa teks, gambar, video, audio, dan animasi lainnya yang di sediakan melalui jalur koneksi internet

\subsection{Database}

Menurut Ario Suryo Kusumo dari bukunya yang berjudul “Administrasi SQL server 2014” (2016), Database adalah kumpulan data yang disimpan dalam media elektronik, saling berhubungan, diorganisasikan dengan baik agar tidak terjadi redudansi atau pergulangan dan inkonsistensi, serta nantinya dapat dimanfaatkan kembali

\section{ANALISIS DAN PERANCANGAN SISTEM}

\subsection{Studi Pustaka}

Studi kepustakaan dilakukan dengan cara mencari referensi dalam pustaka yang berkaitan dengan objek penelitian. Studi pustaka ini penting untuk mendukung data peneliti yang akan diimplementasikan ke dalam perancangan aplikasi.

3.2. Observasi

Metode ini merupakan bahan pembuatan aplikasi pada pelayanan di apotek Bragja dengan deskripsi pada studi kasus. Kegiatan yang dilakukan pada tahap ini mengumpulkan data seperti apotek, data obat-obatan , data-data penjualan sebelumnya, data-data pembelian dan data-data laporan penjualan dan pembelian tersebut.

3.3. Wawancara

Wawancara yang dilakukan penulis adalah dengan tanya jawab oleh pemilik apotek dan bagian yang terkait dalam pengumpulan data. Adapun data yang didapatkan antara lain profil apotek, data obat, data penjualan, data pembelian, dan data laporan yang bersifat teori.

3.4. Tahap Penelitian

Berikut pada pembuatan aplikasi e-commerce ini menggunakan metode SDLC (Software Development Life Cycle) dengan model waterfall. Terdapat 5 (lima) tahap untuk mengembangkan suatu perangkat lunak yaitu Analysis, Design, Coding, Testing, Maintenance: 


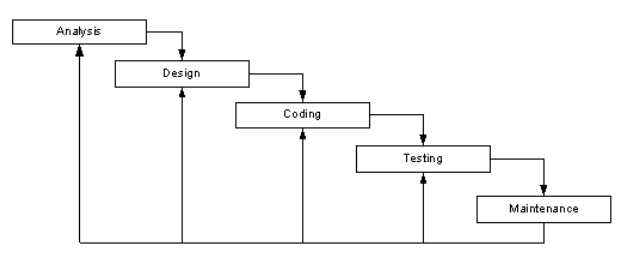

Gambar 1. Tahapan Metode Waterfall

Keterangan:

1. Analisis kebutuhan perangkat lunak (Analysis)

2. Perancangan aplikasi (Design)

3. Pembuatan kode program (Coding)

4. Pengujian (Testing)

5. Pemeliharaan (Maintenance)

\subsubsection{Rancangan User Interface Pemesanan}

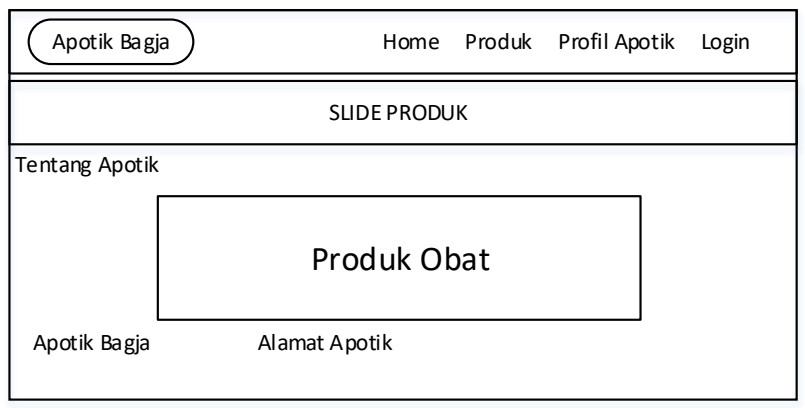

Gambar 2. Rancangan Beranda

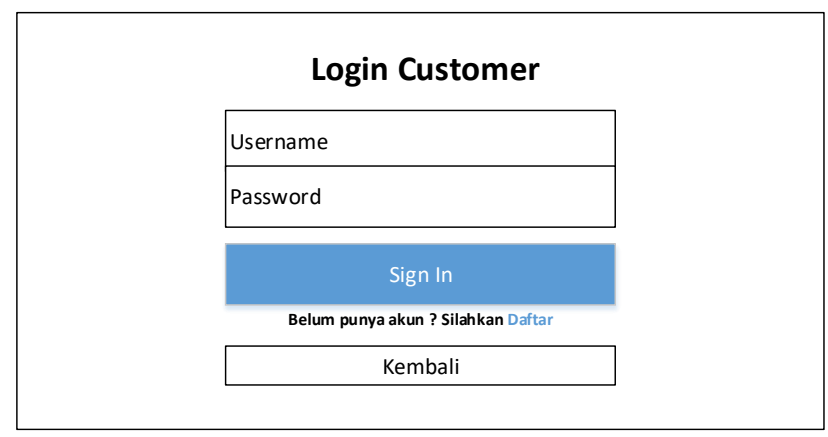

Gambar 3. Rancangan login pemesanan

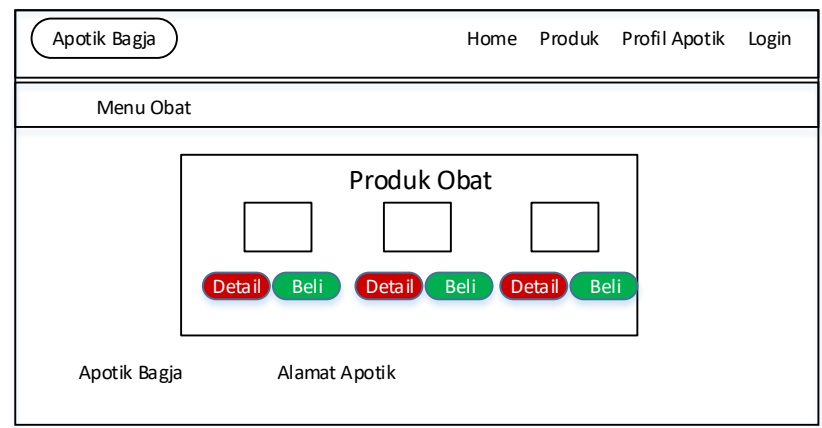

Gambar 4. Rancangan Menu Obat 


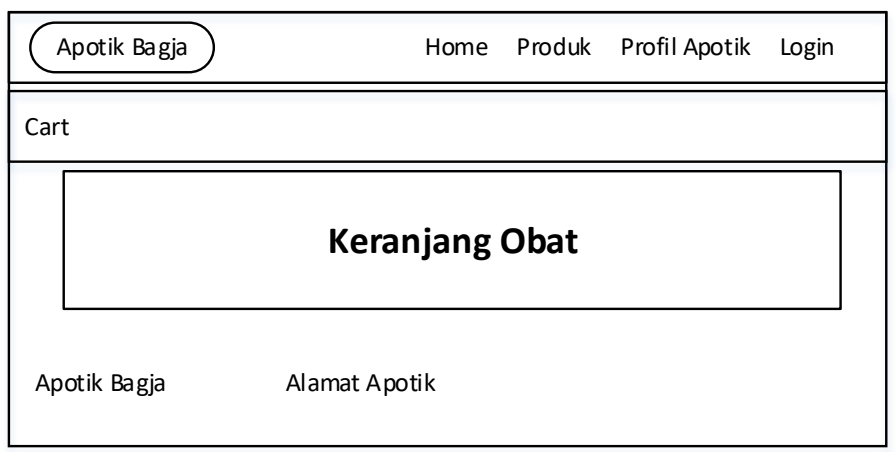

Gambar 5. Rancangan Tampilan Menu Card

\subsubsection{Rancangan Tampilan Dashboard Konsumen}

\begin{tabular}{|c|c|}
\hline Customer & \\
\hline Dashboard & Data Profil Customer \\
\hline Pesan lagi & \\
\cline { 2 - 2 } & Data order obat \\
& \\
\hline
\end{tabular}

Gambar 6. Rancangan Tampilan Dashboard Konsumen

\subsubsection{Rancangan User Interface Admin}

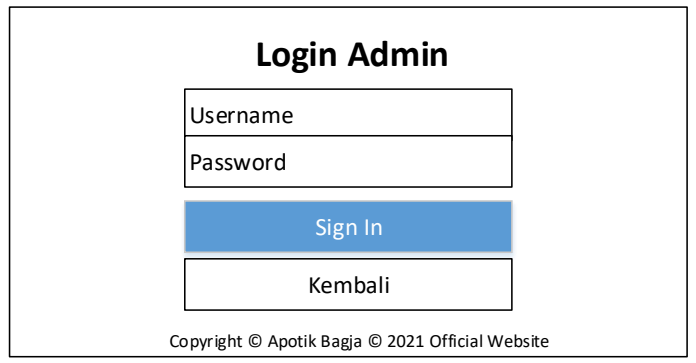

Gambar 7. Rancangan Tampilan Dashboard Admin

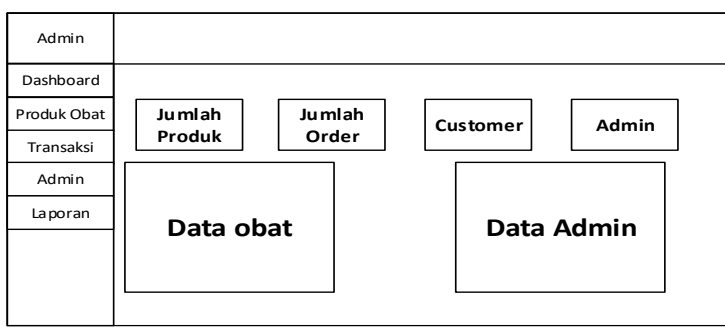

Gambar 8. Rancangan Tampilan Dashboard Admin

Perancangan Aplikasi E-Commerce Produk Obat-Obatan Pada Apotik Bagja Cirebon Berbasis Web (Dika Prasetyo Adhi, Wiwiek Nurkomala Dewi) 


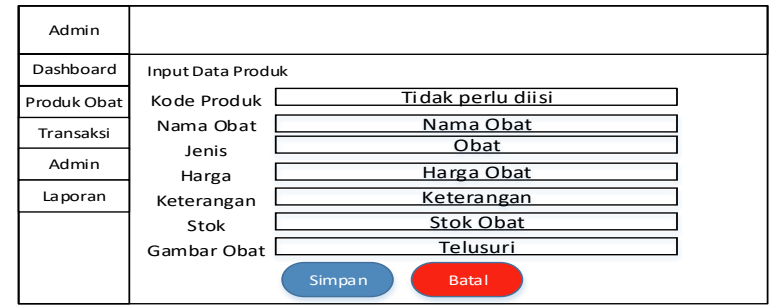

Gambar 9. Rancangan Halaman Input Data Produk

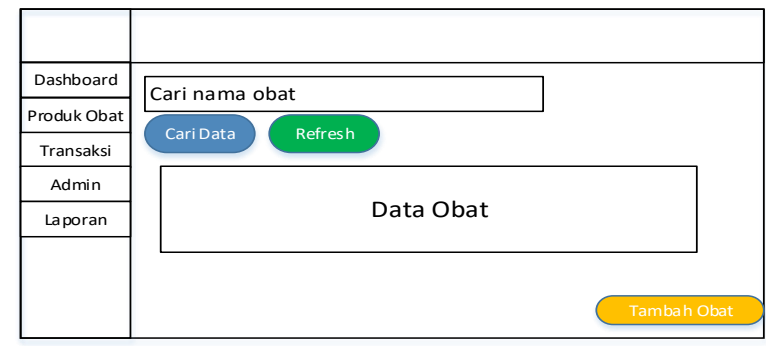

Gambar 10. Rancangan Halaman Data Produk

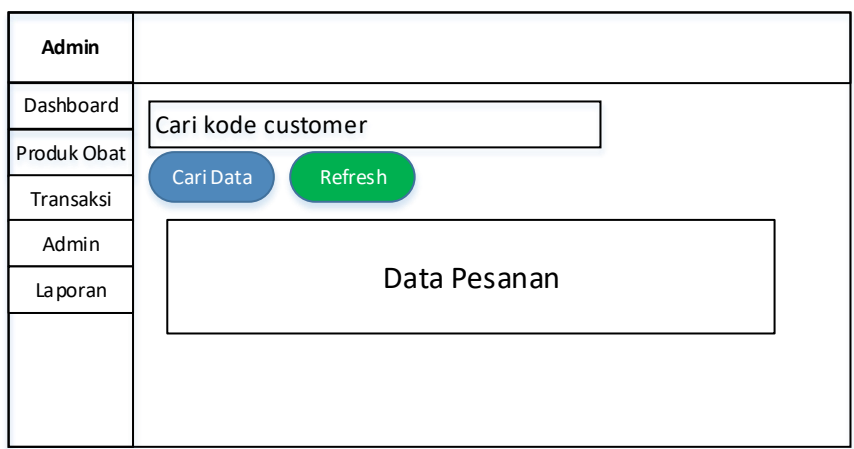

Gambar 11. Rancangan Halaman Data Pesanan

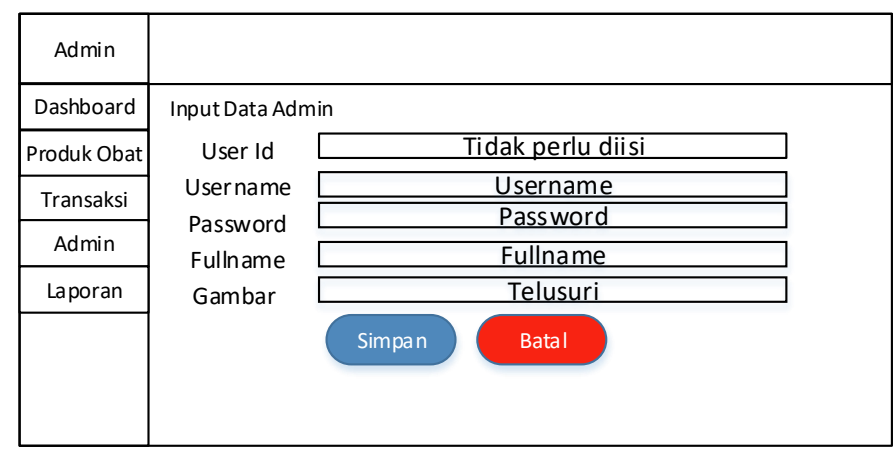

Gambar 12. Rancangan Input Data Admin 


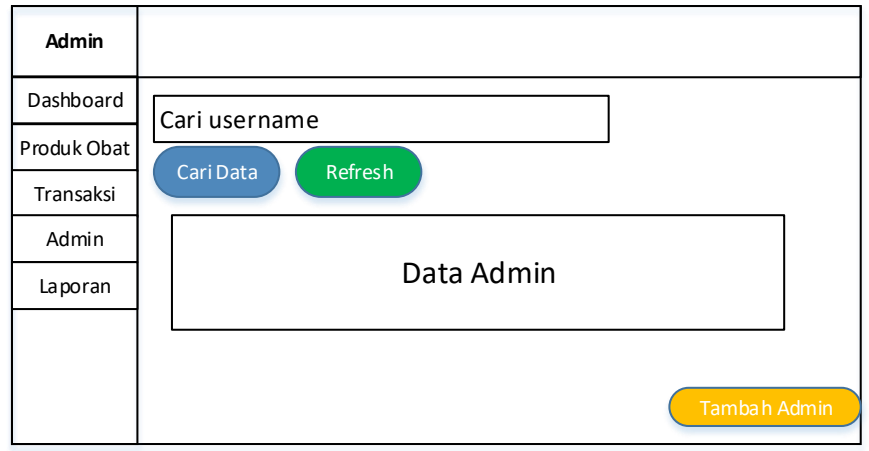

Gambar 13. Halaman Data Admin

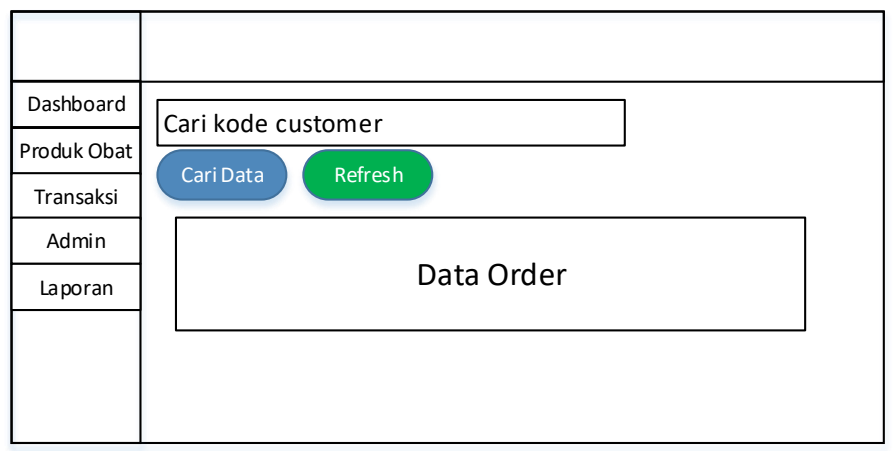

Gambar 14. Halaman Data Order

\section{IMPLEMENTASI DAN PENGUJIUAN}

4.1 Implementasi Halaman Utama Aplikasi Apotek Bagja

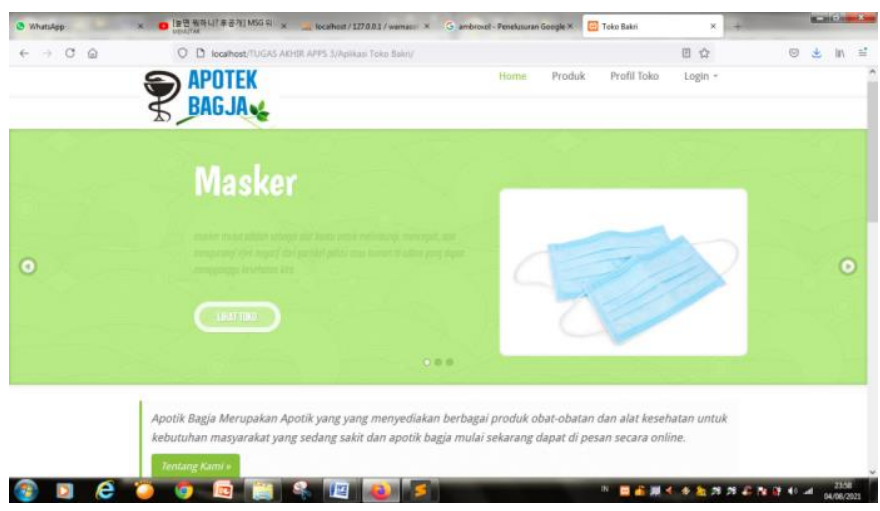

Gambar 15. Implementasi Halaman Utama Aplikasi Apotik Bagja 


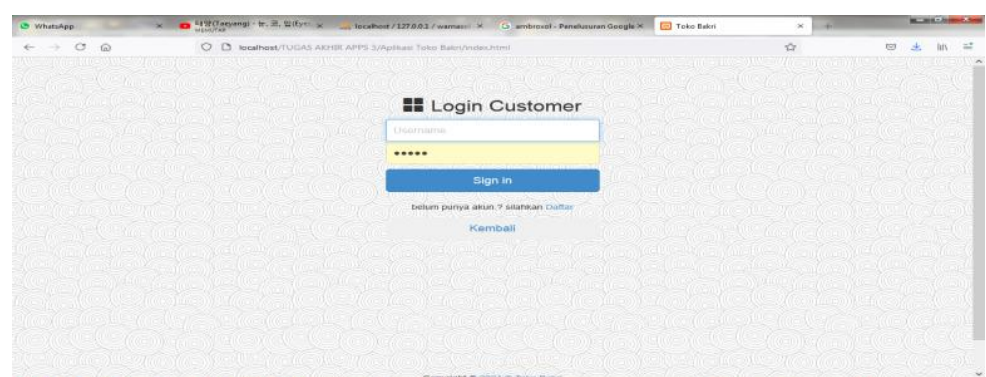

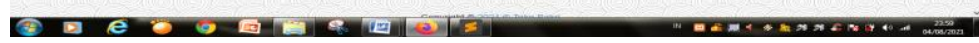

Gambar 16. Implementasi Halaman Login Customer

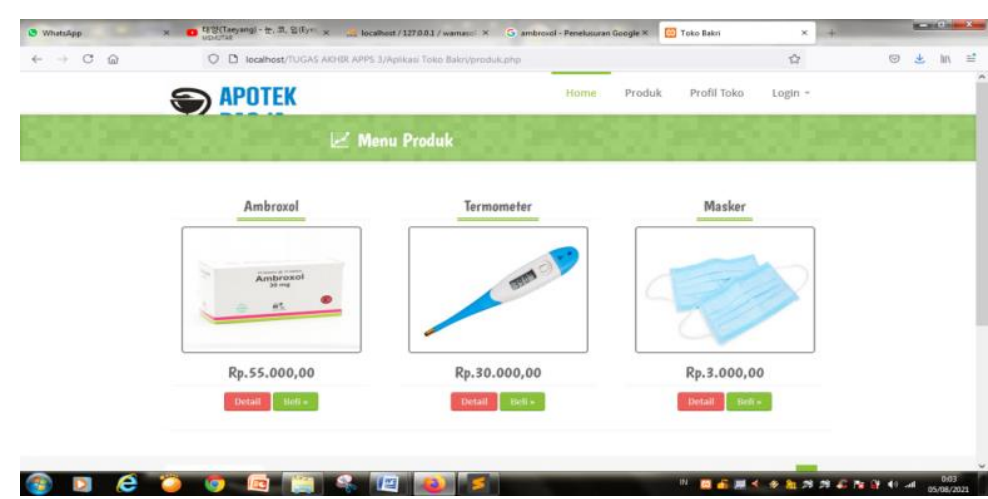

Gambar 17. Implementasi Halaman Produk Obat dan Alat kesehatan

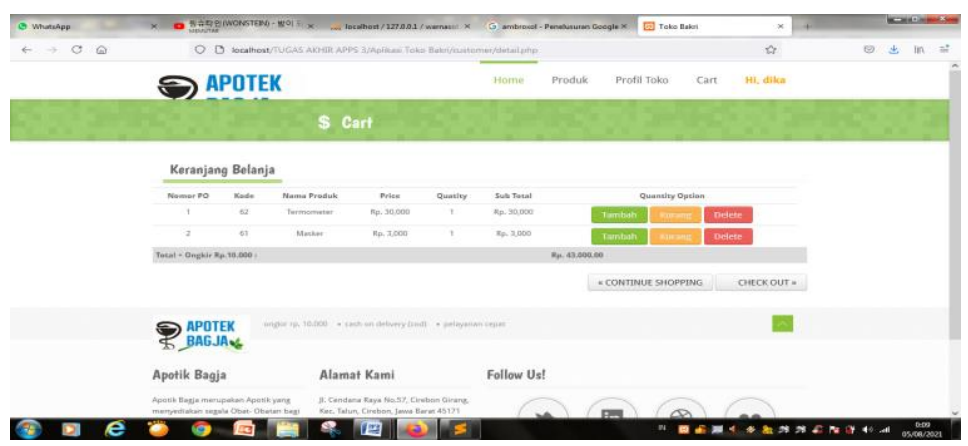

Gambar 18. Implementasi Halaman Pemesanan

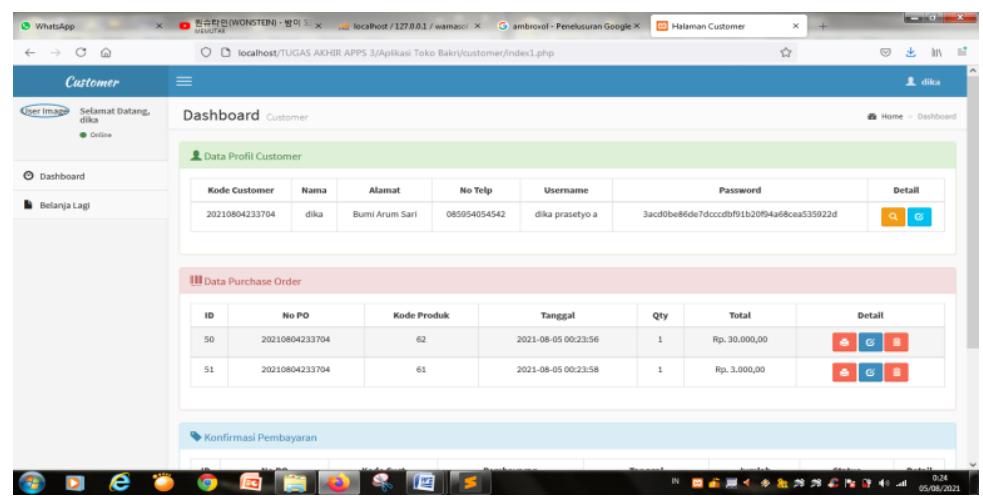

Gambar 19. Implementasi Halaman Check Out Obat 
4.2 Implementasi Halaman Login Admin

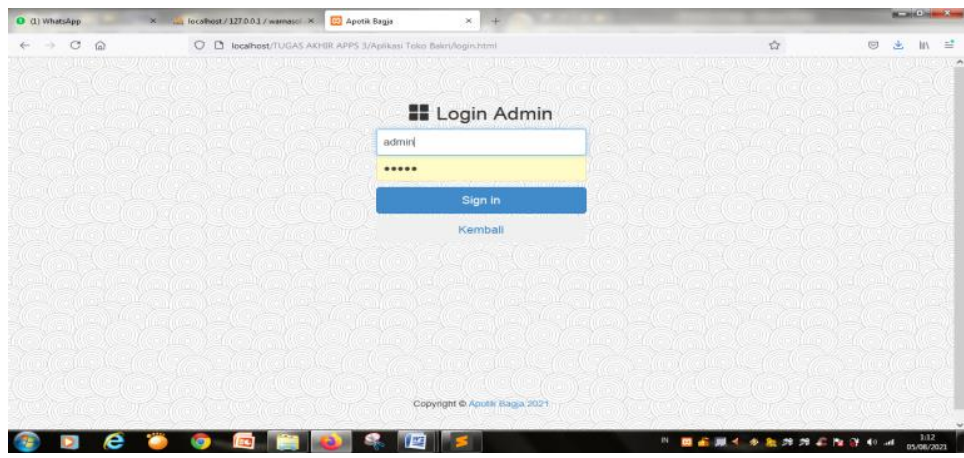

Gambar 20. Implementasi Halaman Login

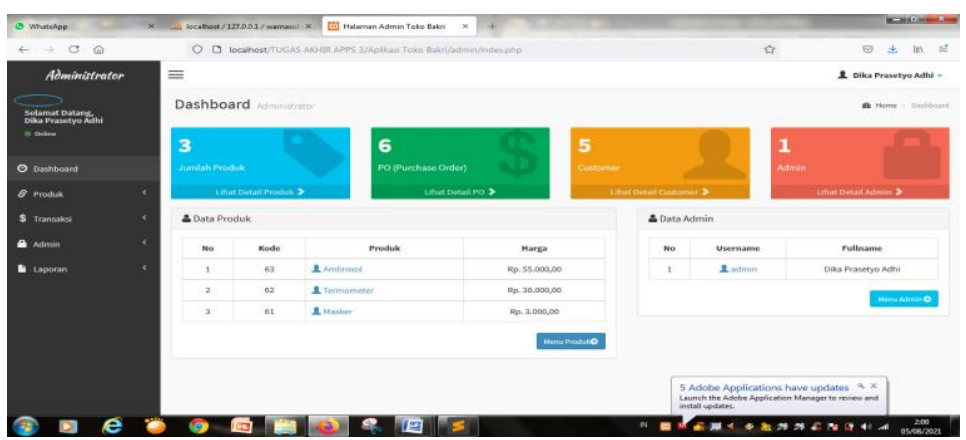

Gambar 21. Implementasi Halaman Dasboard Admin

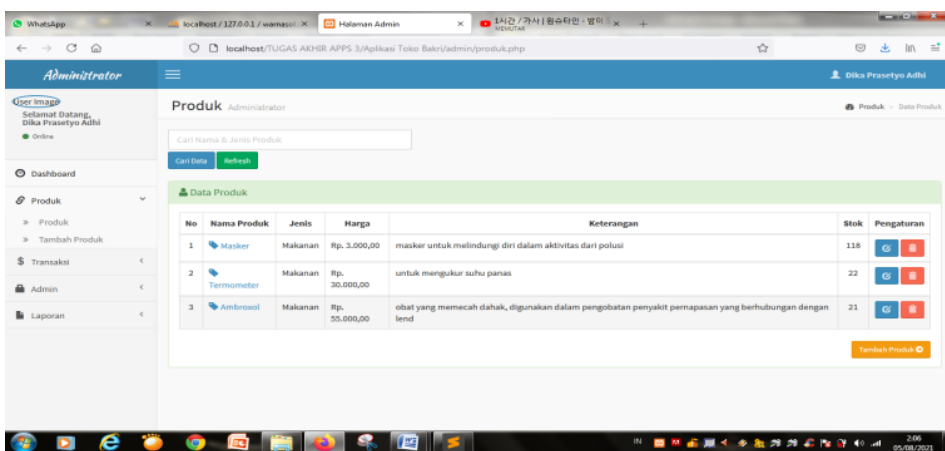

Gambar 22. Implementasi Halaman Produk

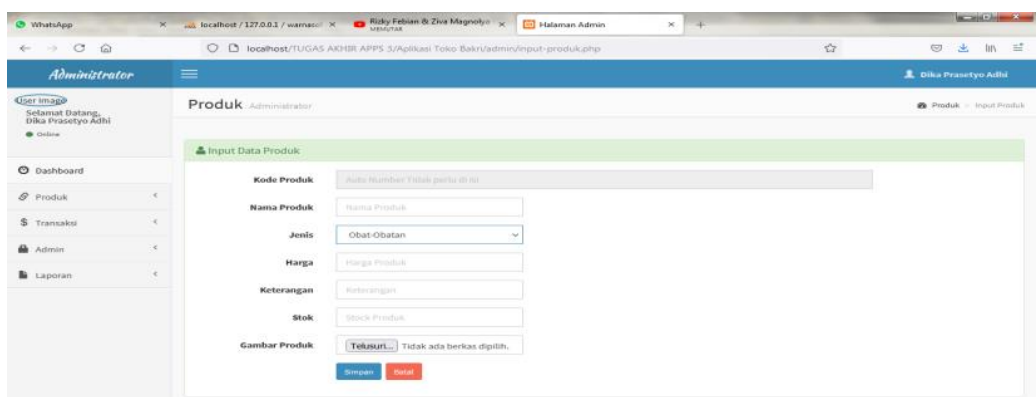

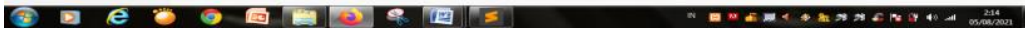

Gambar 23. Implementasi Halaman Input Produk

Perancangan Aplikasi E-Commerce Produk Obat-Obatan Pada Apotik Bagja Cirebon Berbasis Web (Dika Prasetyo Adhi, Wiwiek Nurkomala Dewi) 


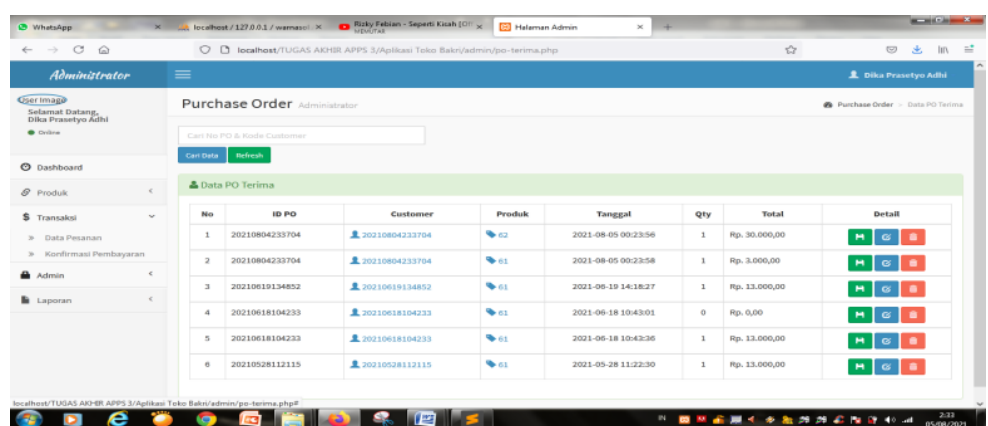

Gambar 24. Implementasi Halaman Transaksi Pesanan
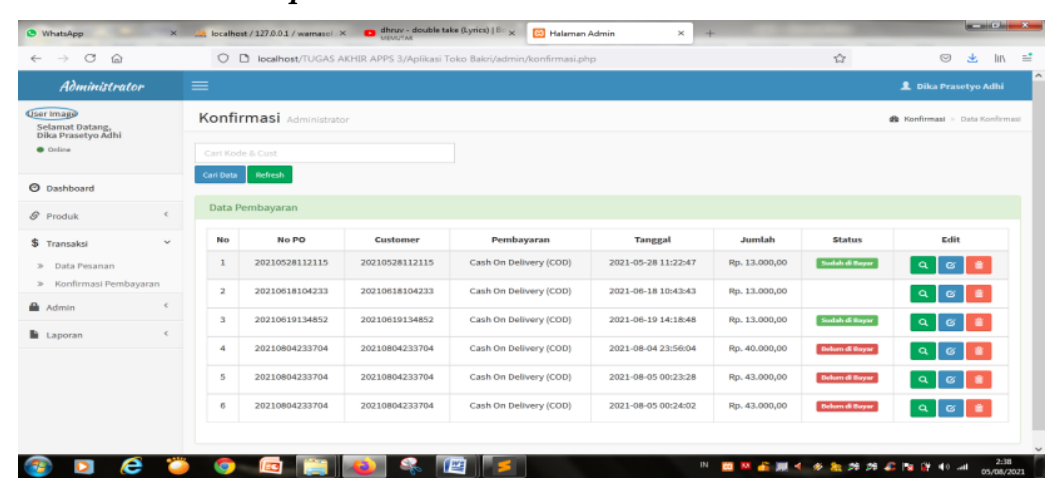
Gambar 25. Implementasi Halaman Konfirmasi Pembayaran

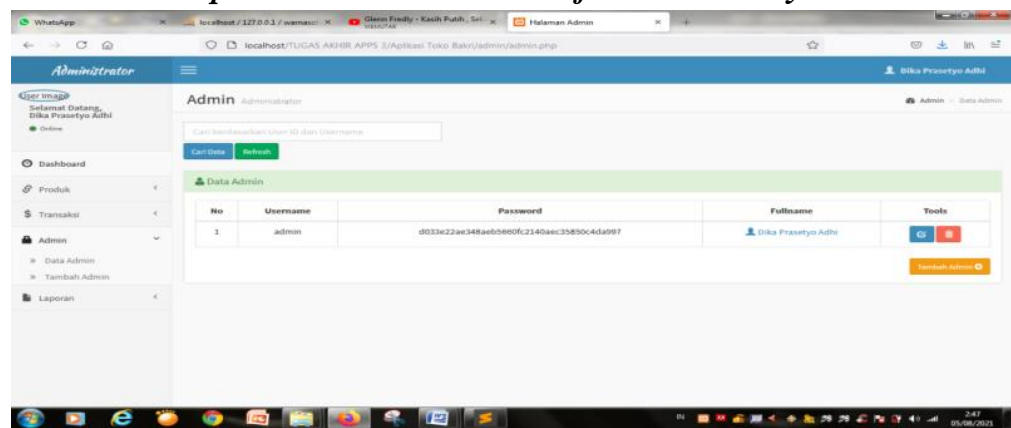

Gambar 26. Implementasi Halaman Profil Admin

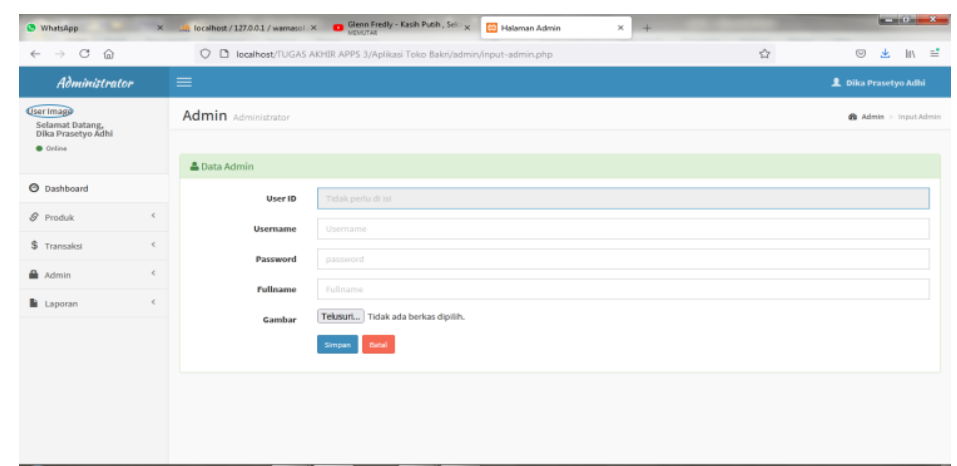

Gambar 27. Implementasi Halaman Input Data Admin 


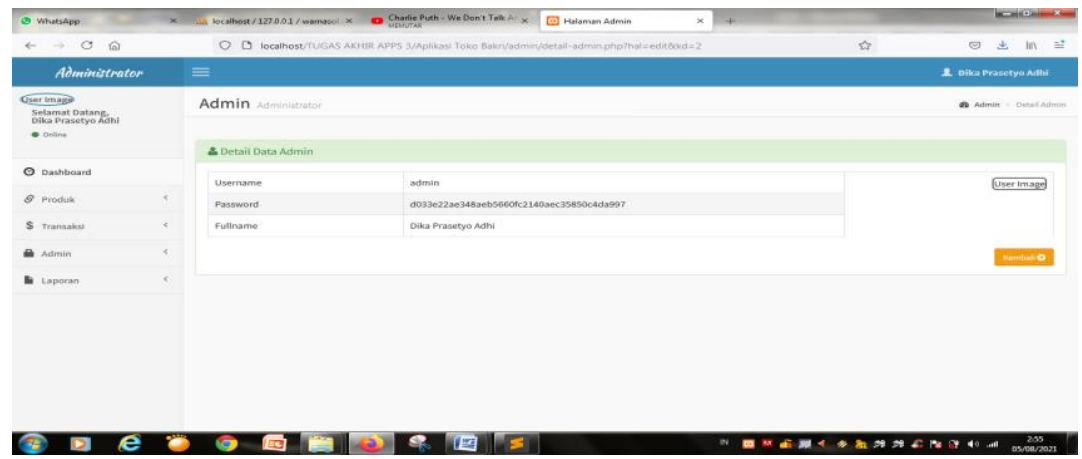

Gambar 28. Implementasi Halaman Profil Admin

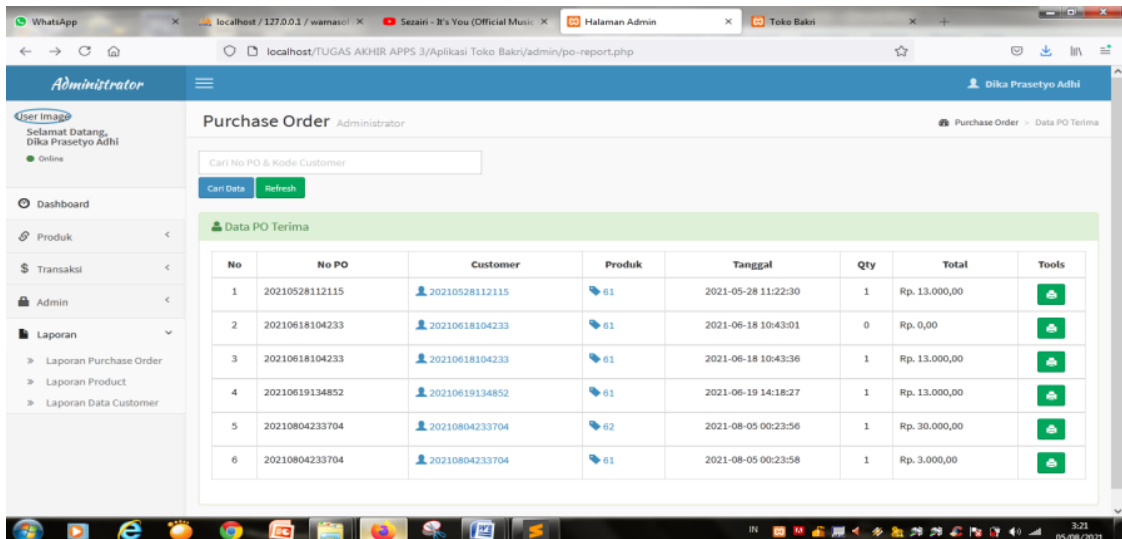

Gambar 29. Implementasi Halaman Laporan

\section{KESIMPULAN}

Sesuai dengan tujuan penulis dalam penelitian ini, penulis telah menyelesaikan perancangan aplikasi e-commerce yang telah dirancang untuk Apotek Bagja. Aplikasi yang telah dirancang memiliki manfaat yaitu sebagai bahan pengelolahan obat-obatan, alat-alat kesehatan yang lebih efektif dan terkomputerisasi didalam system. Selain itu, pelanggan atau costumer dapat membeli dan memesan produk melalui aplikais e-commerce yang telah dirancang. Serta untuk karyawan apotek Bagja sudah lebih efektif dalam melakukan pekerjaan secara komptuterisasi melalui aplikasi yang telah dibuat.

\section{DAFTAR PUSTAKA}

[1] Asiya, (2020).“Aplikasi Daftar Hadir Pengunjung Perpustakaan Pada Universitas Catur Insan Cendekia Kota Cirebon”. Tugas Akhir. Fakultas Teknologi Informasi, Manajemen Informatika, Universitas Catur Insan Cendekia.

[2] Anggis, Rona Relita. (2020). "Sistem Informasi Rekap Data Laporan Tugas Akhir Alumni Pada Universitas Catur Insan Cendekia Kota Cirebon Berbasis Website". Tugas Akhir. Fakultas Tekonologi Informasi, Manajemen Informatika, Universitas Catur Insan Cendekia.

[3] Wahyudi, Fajar Ramadhan. (2020). “Aplikasi Web Portal Manajemen Informatika Berbasis Website Dengan Menggunakan Framework Code Ingniter Dan Mysql Pada Universitas Catur Insan Cendekia". Tugas Akhir. Fakultas Teknologi Informasi, Manajemen Informatika, Universitas Catur Insan Cendekia.

Perancangan Aplikasi E-Commerce Produk Obat-Obatan Pada Apotik Bagja Cirebon Berbasis Web (Dika Prasetyo Adhi, Wiwiek Nurkomala Dewi) 
[4] Agfan, Fadillah. (2020). "Mengukur Kualitas Pelayanan Dan Kepuasan Konsumen Pada Indomart Wahidin Dengan Importance Performace Analysis (IPA) Dan Customer Satisfaction Index (CSI)”. Tugas Akhir.Fakultas Manajemen Bisnis, Univesitas Catur Insan Cendekia.

[5] Rozaq, A. (2019). Sistem Basis Data MySQL Pada Konsep Jaringan Klien Server. Yogyakarta: Poliban Press .

[6] Raharjo, Budi. 2011. Membuat Database Menggunakan Mysql. Informatika. Bandung.

[7] Sudaryono, S., Rahwanto, E., \& Komala, R. (2020). E-COMMERCE DORONG PEREKONOMIAN INDONESIA, SELAMA PANDEMI COVID 19 SEBAGAI ENTREPRENEUR MODERN DAN PENGARUHNYA TERHADAP BISNIS OFFLINE. Jurnal Manajemen Dan Bisnis, 2(02), 110-124.

[8] Ahmad Mustofa, Mutmainah. 2015. "Perancangan E-Commerce Penjualan Komputer Dan Alat Elektronik Berbasis Web Pada Toko Damar Komputer Pringsewu.” Jurnal TAM ( Technology Acceptance Model ) 4(1):62-67.

[9] Wulandari, Siska Aprilia. 2015. "Sistem Informasi Penjualan Produk Berbasis Web Pada Chanel Distro Pringsewu.” Jurnal TAM ( Technology Acceptance Model ) 4(1):41-47.

[10] Anggraini, Elisabet Yunaeti, And Ratnasari. "Perancangan Aplikasi E-Commerce Pada Toko Jam Tangan Alexander.” Jurnal TAM (Technology Acceptance Model) 2 (2017). : 20-25.

[11] Rerung, R. R. (2018). Pemrograman Web Dasar. Deepublish

[12] Irawan, Dedi, Yoeyong Rahsel, dan Taufik Udin. 2017. "Perancangan Electronic Commerce Berbasis B2C Pada Toko Atk Sindoro.” Jurnal TAM ( Technology Acceptance Model ) 8(1):58-62.

[13] Sadeli. (2013). Toko Baju Online Dengan PHP dan MySQL. Palembang: Maxikom.

[14] Himawan, H., Saefullah, A., \& Santoso, S. (2018). Analisa dan Perancangan Sistem Informasi Penjualan Online (E-Commerce) pada CV Selaras Batik Menggunakan Analisis Deskriptif. Scientific Journal of Informatics, 1(1), 53-63. 